\title{
Modeling the Communications of Dayak Meratus Ethnic in Producing Forest Myths in Hulu Sungai Tengah and Balangan District
}

\author{
Fahrianoor \\ Faculty of Social and Political Sciences \\ Lambung Mangkurat University \\ Banjarmasin, Indonesia \\ Susanne Dida \\ Faculty of Communication Science \\ Padjadjaran University \\ West Java, Indonesia
}

\author{
Edwin Rizal \\ Faculty of Communication Science \\ Padjadjaran University \\ West Java, Indonesia \\ Herlina Agustin \\ Faculty of Communication Science \\ Padjadjaran University \\ West Java, Indonesia
}

\begin{abstract}
Dayak Meratus ethnic interacts with forests in their daily life to create a distinctive culture. This distinctive culture is forest itself, in which the community life relies on forests. The forest is classified into three parts based on customary agreements. They are managed forest, customary forests and sacred forests. This classification is developed by forming symbols and myths about forest. These symbols and myths create communication model between Dayak Meratus ethnic communities and forests. The focus of this article is to know how the communication model of Dayak Meratus ethnic in conserving forest is. The research of this article uses qualitative approach using ethnographic communication method developed by Dell Hymes with speaking model. The communication model of Dayak Meratus ethnic in producing myths and symbols about the forest is in speech communication, myth and symbol of forests are generated from generation to generation. The myths and symbols are applied in agricultural tradition and Kaharingan religious tradition of Dayak Meratus Ethnic.
\end{abstract}

Keywords-communication model; Dayak Meratus ethnic; forest

\section{INTRODUCTION}

Dayak is a tribe living in the forest area with their all social activities. They have their own understanding and meaning to the forest according to their experience on it. As Dayak Tepian Sungai (Ut danum/river bank) and those Dayak Bukit (mountain). They cannot be separated from the myths and symbols inherent in their daily life. These myths and symbols are able to guide their system of interaction with the forest.

For Dayak Bukit known as Dayak Meratus have sumbayang ceremony (Prayer) to rice. They pray to gods who maintain the rice, land dan trees. They also pray to ancestors who have guided them about good farming practices [1, p. 246]. For Dayak Bukit tribe believes that forest and land are the source of livelihood for them. For this tribe, forest utilization is always associated with customary law and authority. Syahruji [2, p. 121] states that Dayak Kiyu community in particular and Dayak Meratus generally, forest and customary land is their life. Forests are pharmacies, food barns, kitchens, learning sites and banks. Forest is also like a mother who must be respected for giving life. Whereas, the tradition is the root of life. So the terms created by Dayak Meratus community are forestry base. For example, akar kehidupan (root of life); this suggests that tradition is the lifeline.

Traditionally, Dayak Meratus indigenous community manages customary forests and their natural resources cannot be separated from customary law. As the practice of farming may be in the area of cultivation only, not allowed to cut timbers in the sacred territory. It is believed that if the forest destroyed, the tradition also will be extinct. Violations will be subjected to customary sanctions as stated in recent customary law.

Referring to the above explanation, this article aims to model Dayak Meratus Ethnic communication in producing forest symbols and to analyze Dayak Meratus ethnic communications model with forest.

\section{Methodology}

This research is qualitative with ethnographic communication method. As proposed by Hymes in [3, pp. 208209], it is a model that abbreviated by "speak-ing” that stands for setting/scene, participants, ends, act sequence, keys, instrumentals, norms of interaction, genre. This means that each of these sections become the focus unit of the analysis in studying the communication reality of Dayak Meratus ethnic community. 
The subject of this research is the indigenous community of Dayak Meratus ethnic located in two areas of Hulu Sungai Tengah and Balangan district in South Kalimantan Province. In these both areas, Dayak Meratus ethnic community occupies the area along Meratus Mountains.

Data analysis technique is an important part in conducting research. Data analysis is the process of organizing and sorting into the patterns, category and basic description so that the data can be collected as targeted to get a conclusion. As stated by Creswell [4, p. 152-153], techniques in ethnographic research are description, analysis, and interpretation.

\section{FINDINGS}

\section{A. The Rise of the Myths in Dayak Meratus Ethnic}

The traditional life of Dayak Meratus ethnic always adheres to the tradition of cultural ancestry happens for generations. The proof of cultural sustainability is reflected in the tradition of farming applied in various traditional ceremonies. The farming activity is embedded in Dayak Meratus ethnic culture, both in Hulu Sungai Tengah district, Balai Adat Kiyu and Balangan district in Balai Halong Adat. The farming activity is identical to the forests and it is limited by law that should be obeyed. The law can be seen in myths and symbols that always exist in various farming activities.

Makurban, the chief of Balai Adat Kiyu states that:

"The existing myths in Dayak Meratus ethnic culture were derived from our ancestors, what we do now is what that have been inherited from Abah Uma (Father, mother). We are their generations, if Abah Uma lie to us, we will also lie with these myths. Hence, so far it is just fine for us. These myths are stories, bans, or customary restrictions which are regulated by culture particularly during ceremonies. The myths and symbols can be a story about the origin of our datu nini, mamangan (magic spell), and offerings in ceremonial accessories." (Interview, August 20, 2017)

The most traditional Dayak Meratus ethnic mostly have livelihood on farming and gardening. They lived on the edge of forest because they previously lived in that area before they established a village. Previously, they lived in the forests separately between an umbun (family) and another. This way of life was caused by their nomadic agriculture in the period of 4 to 5 years.

The existing myths found in Dayak Meratus ethnic both in Balai Adat Kiyu in Batang Alai Timur sub district and Balai Adat Halong have same elements. Makurban states that the myths evolved in these two traditional halls were derived from previous ancestors, it was orally told to the generations of Dayak Meratus Ethnic.

Makurban (interview, 22 August 2017) narrated that the origin of the indigenous Dayak Meratus' ancestors was from lowlands to the coast. After many migrants came (Banjar traders or others), the indigenous Dayak Meratus community gradually migrated to upstream of some rivers and Meratus mountains. The migration happened was due to the cultural differences and self-defense. The prolonged social conflicts of economic and religious issues especially the spread of religion, and the domination of fertile agrarian caused Dayak Meratus indigenous community lived in Meratus Mountains until now. The another clue that could support the statement that the origin of Dayak Meratus was from coastal area that is a number of traditional ceremonial accessories symbolize the life in the estuary of the river or coast. The ceremonial accessories which have symbolic meanings are parahu malayang (floating boat), tihang layar (boat's mast), and balai bajalan (moving hall) including other terms used in traditional ceremonies. Here are some legends that developed in Dayak Meratus ethnic community, in this case Balai Adat Kiyu.

Dayak Meratus from Balai Adat Halong also has myth like Dayak Meratus ethnic from Balai Adat Kiyu. It also relates to the forest. The people of Balai Adat Halong have a belief to the spirit of the ancestors. Every one cannot be separated from their belief. Mr. Chairil, the chief of Balai Adat Halong proposed that most of Balai Adat Halong people believe in the spirit of their ancestors. This belief leads all the behavior of Balai Adat Halong people. It is adhered from generations to generations. In addition, it is concerned in various traditional ceremony annually. This ceremony is called as aruh. In Dayak's custom, there are many aruh conducted including aruh for new farming area establishment that usually held on September. The existing myth becomes a part of our belief derived from our parents' stories. (Interview, November 12, 2017)

\section{B. Function of Myth for Dayak Meratus Ethnic}

The myths was developed in Dayak Meratus ethnic, both Balai Adat Kiyu and Balai Adat Halong. From the above explanation related to the divine conception based on their belief. The belief is based on two fundamentals such as, help and threats. The help relates to the functions that they obtained particularly farming and gardening activities. Suliman, 41 (Chief of Padang) Balai Adat Kiyu Traditional stated:

"For us, Dayaks, the yearly cultivation activity is part of worship. The cultivation of fields inherited by ancestors require us to make offerings to the spirits of our ancestors. Besides the offering to ancestors, we also offer gifts to the guardians of nature, rivers, forests, wind, fire and land. So, if we do not bahuma (farm) means there is no aruh (ceremony). Therefore, this means that there is no worship.” (Interview, August 23, 2017)

As for those related to threats, the ceremony is related to salvation. The salvation of disasters were caused by some spirits who feel disrespected and not served.

There are two fundamental functions of the myth. There are the myth which serves to create fear and threats for Dayak Meratus ethnic and myth related to help. Both of these myth functions are embodied in forms of Dayak Meratus ethnic ceremony which in the form of ganal aruh (big ceremony) that full of offerings. Aruh (ceremony) is close related to their life activities in the forest, especially the farming activities every year. 


\section{Discussion}

The existence of myths in Dayak Meratus ethnic does not appear without a cause. The data shows the existence of these myths are caused by the communication happened in social life of Dayak Meratus ethnic. The myths were derived from the ancestors of Dayak Meratus ethnic. They were inherited from generation to generation through a way of telling stories. In Dayak Meratus ethnic social practice, these myths are believed and maintained. As suggested by Ralph Larossa and Donald C. Reitzes (1993) in [5, p. 96], symbolic interactions essentially explain the frame of reference to understand how human and others create a symbolic world and how the world builds human behavior.

Referring to the theory of symbolic interaction, the source of the myths that arise and develop in Dayak Meratus ethnic derived from a family reference as group or community. It happened from generation to generation, and has built human behavior. The limit of understanding on the forests reality, Dayak Meratus ethnic acknowledged the existence of the myths communicated by the ancestors. Whereas, their life becomes part of the forest itself. Besides that, the myths are also communicated in the form of traditional ceremonies take place in Dayak Meratus ethnic community.

The reference of the myths in Dayak Meratus ethnic originating from story is surely related to the subjective human experience. This subjective experience as proposed by Schutz (1899-1959) in [6, p. 94]. He states that in this inter-subjective world, people create social reality. It is compelled by the existing social reality and by the cultural structures of their ancestors' creation. In the world of life, there are many collective aspects, but there is also personal aspect. Schutz, distinguishes the world of life between close relationship (our relations) and impersonal and space relationships (their relations). While intimate relationship are so essential in the world life.

In addition, the existing myths in the life of Dayak Meratus ethnic have two fundamentals functions, such as related to threats and help. One example of myths that threatens is the myth of the pangeran (Scary spirit), it likes to disturb humans. This myth is certainly related to human desire to have security, then in everyday life, the figure of pangeran is honored by offerings that happen in every full moon.

The myth associated with help is a myth that can bring benefits to Dayak Meratus ethnic. As example, myth putir (comforter spirit), it can nourish the soil, the roots of trees and fruits. The myth as the figure of putir is so respected and always be given offerings in every traditional ceremony.

Both of these are certainly related to myths considered to have benefits and functions for human. Vegeer [7, p. 171] proposes that viewing social reality as a social behavior that has subjective meaning, hence behavior has purpose and motivation. In addition, Weber states that social behavior becomes social if the subjective of social behavior makes the individual guides and considers other behavior that guides to that subject. The behavior has certainty if it shows uniformity with behavior in general in society
Related to the function and benefit of the myth, both threatening or Scary, and myth which is believed help. This is certainly related to the subjective meaning of human, because the meaning of human beings have purpose and motivation. Safety and freedom from threats also become the desire of Dayak Meratus Ethnic. Likewise, the meaning of welfare is contained in the myth of putir (good spirit) that can fertilize the soil, and keep the fruits, which grow in the forest area.

Either the background of myths, which is the product of the ancestor of Dayak Meratus ethnic, or from the functions of these myths to form communication of Dayak Meratus ethnic with forest. This communication is viewed from the behavior of Dayak Meratus ethnic to the forest. They considered the respected spirits live in the trees grown in the Meratus mountain forests. Littlejohn and Karen A. Foss [8, p. 344] state that the environmental communication is a discipline of communication science, including interdisciplinary meta fields. Theory and field research are unified by focus on the topic of environmental communication. It is closely related to the way of people communicate, especially about nature. This means that when Dayak Meratus ethnic respect the spirits considered important then it is related to their respect for nature (forest). Here is a model of communication that create myths of Dayak Meratus Ethnic.

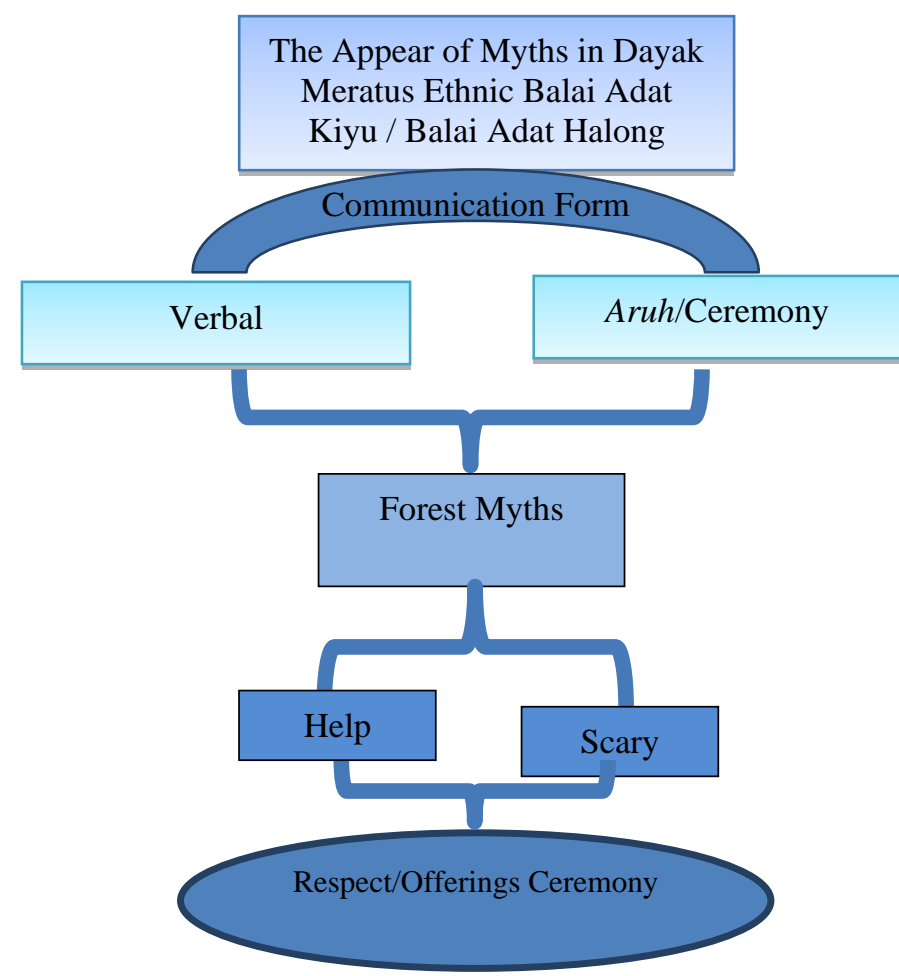

Fig. 1. Model of Modeling Communication of Dayak Meratus Ethnic in Making Forest Myths

\section{CONCLUSION}

Myths of forests emerging in Dayak Meratus ethnic communities are through the tutor's communication process (storytelling) and through aruh tradition (traditional ceremony of Dayak Meratus ethnic). The myths about forest of Dayak 
Meratus ethnic can be classified into two, such as; the myths of scary and the myths of help.

Both the Scary myths and the help myths are as spirits that must be respected by Dayak Meratus Ethnic. The form of honor is by offerings like cakes or foods.

\section{ACKNOWLEDGMENT}

Thia research is fully support from Direktorat Riset dan Pengabdian Masyarakat, Direktorat Jenderal Penguatan Riset dan Pengembangan Kementeian Riset, Teknologi, dan Pendidikan Tinggi, Republik Indonesia.

\section{REFERENCES}

[1] N. H. Radam, Religi Orang Bukit [Hill People’s Religion]. Yogyakarta: Semesta, 2001.

[2] A. Syahruji, B. Kiyu, "Masyarakat Adat Dayak Kiyu Meratus, Kalimantan Selatan: Pengelolaan Hutan Masyarakat Adat Dayak Kiyu [The Kiyu Dayak Indigenous Community, Meratus, South Kalimantan:
Strengthening alliances to campaign for forest protection],” in Hutan untuk Masa Depan: Pengelolaan Hutan Adat di Tengah Arus Perubahan Dunia [Forests for the Future: Indigenous Forest Managament in a Changing World], E. O. Kleden, Y. Indradi, L. Chidley, Eds. AMAN and Down to Earth, 2013, ch. 5, pp. 105-135.

[3] A. S. Ibrahim, Panduan Penelitian Etnografi Komunikasi [Etnography Communication Research Guidance]. Surabaya: Usaha Nasional, 1994.

[4] J. W. Creswell, Qualitative Inquiry and Reseach Design : Chooosing Among Five Traditions, London: Sage Publications, 1997, pp. 152-153.

[5] R. West and L. H. Turner. Pengantar teori Komunikasi: Analisis dan Aplikasi. Buku 1. [Communication Theory Introduction: Analysis and Application, Book 1] (Transl. M. Natalia, Transl.), 3rd ed., Salemba Humanika, 2008.

[6] G. Ritzer dan D. J. Goodman, Teori Sosiologi Modern, terjemahan Alimandan [Modern Sociology Theory (Alimandan, Transl.)]. Jakarta: Kencana, 2007.

[7] K. J. Vegeer, Realitas Sosial, Refleksi Filsafat Sosial Atas Hubungan Individu Masyarakat Dalam Cakrawala Sejarah Sosiologi [Social Reality, Social Phylosophy Reflection of Society's Individual Relationship in Sociological History's Horizon]. Jakarta: Gramedia, 1993.

[8] S. W. Littlejohn and K. A. Foss, Encyclopedia Of Communication Theory, Washington DC: Sage Publication, 2009. 